\title{
ENVIRONMENTAL IMPACT EVALUATION OF INNOVATION IN TRADITIONAL FOOD PRODUCTION LINES. PART I: METHODOLOGICAL FRAMEWORK
}

\author{
Ilja Gasan OSOJNIK ČRNIVEC ${ }^{1}$, Romana MARINŠEK-LOGAR ${ }^{2}$
}

Received October 14, 2009; accepted January 20, 2010

Delo je prispelo 14 . oktobra 2009, sprejeto 20. januarja 2010

\begin{abstract}
Environmental impact evaluation of innovation in traditional food production lines. Part I: methodological framework

In order to improve the knowledge on environmental impacts of current production systems and to find the solutions to reduce the negative impacts effective multi-approach environmental assessment methodologies are required. The environmental impacts assessed in complex systems, such as agriculture and food production, are prone to higher uncertainties. Therefore, field-specific standardization of the assessment procedures based on multiple screening studies are required to make the assessment outcome less vulnerable. The procedure array pairing for the formation of production step emission inventory is an important methodological process in environmental impact assessment. Initial production data was coupled with specialized databases, models found in scientific literature and environmental category characterization guidelines in order to construct an environmental impact methodological framework specific to four case studies of traditional food production.
\end{abstract}

Key words: food industry / traditional food products / environmental impact / environmental protection

\section{INTRODUCTION}

There are many methods that include elements of environmental impact assessment, yet only a few of these allow a multi-approach comprehension of the environmental load.

The set of agri-environmental indicators to be considered ultimately is proposed with great analogy by various governmental and international authorities involved in impact assessment. The European Environ-
Ocenjevanje okoljskih vplivov inovacij v proizvodnji tradicionalnih živil. 1. del: metodološko ogrodje

Analiza okoljskih vplivov dejavnosti agroživilskega sektorja je večplastno opravilo, ki nas pogosto privede do precej negotovih ocen. Oceno vpliva na okolje, v kateri hkrati obravnavamo več vidikov obremenjevanja okolja, lahko izboljšamo s področno-specifično standardizacijo postopkov presoje, ki temelji na podlagi konkretnih primerov iz proizvodnje. Oblikovanje nabora postopkov za pripravo emisijske evidence posameznih proizvodnih korakov je pomemben proces ocenjevanja vplivov na okolje. $\mathrm{V}$ našem delu smo eksperimentalne in proizvodne podatke podprli s specializiranimi zbirkami podatkov, modeli iz strokovne literature ter smernicami za karakterizacijo okoljskih kategorij. Predstavljen metodološki okvir smo oblikovali za oceno okoljskega vpliva štirih primerov iz proizvodnje tradicionalnih živil.

Ključne besede: živilska industrija / tradicionalna živila / vplivi na okolje / varstvo okolja

mental Agency (set of agri-environmental indicators under the acronym "IRENA", EEA, 2006), the American Environmental Protection Agency (EPA, 2009), the U.S. Department of Agriculture (Agricultural Resources and Environmental Indicators, USDA, 2006) and the Organization for Economic Cooperation and Development (Environmental Indicators of Agriculture, OECD, 2001) all observe the environmental impact of agriculture from the shared viewpoints of soil, air and water quality, climate change, land consumption, biodiversity, ecosystems

1 Nat. Inst. of Chemistry, Lab. for Environmental Sciences and Engineering, Hajdrihova 19, SI-1001 Ljubljana, Slovenia, Assist., e-mail: gasan.osojnik@ki.si

2 Univ. of Ljubljana, Biotechnical Fac., Dept. of Animal Science, Groblje 3, SI-1230 Domžale, Slovenija, Prof., Pd.D., M.Sc., e-mail: romana.marinsek@bf.uni-lj.si 
and human health. More detailed the focus of EEA's agriculture eco-efficiency indicators points to indicators such as energy use, irrigation, emissions of greenhouse gases, acidifying substances and tropospheric ozone precursors.

At the beginning of the environmental impact assessment, the environmental consultant is faced with a set of generic recommendations for the environmental assessment framework elaboration. Therefore, the procedure for the environmental impact assessment prior to the emission inventory construction can vary even for the environmental impact studies of the same specific field as it is dependent upon the expert selection.

Due to the controversy of the procedures applied prior to the emission inventory phase, the methodological frameworks are rarely available or even mentioned in the literature. Nevertheless, it is our opinion, that the pool of the combined data transformation calculations presented beside the environmental impact results of the case studies represents a relevant source for the field specific standardization of environmental impact assessment procedures.

In this part, we present the methodological framework devised for the environmental impact assessment of four case studies (fertility management of Brassica sp., dairy cow nutrition, milking frequency and ham cure composition).

\section{METHODS}

\subsection{LIFE CYCLE ASSESSMENT}

LCA is a process of evaluating the effects that a product has on the environment over the entire period of its life. It can be used to study the environmental impact of either a product or the function the product is designed to perform. LCA is commonly referred to as a "cradle-to-grave" analysis (EPLC, 2009). Because of their high relevance, good quality and availability of data, the environmental indicators derived from LCA are reported to be effective (Tomassen and De Boer, 2005).

The LCA method is governed by a group of the ISO 14000 environmental management standards (ISO 14040) and is being both promoted and enforced in the European Union (EC-JRC, 2009) and the USA (EPA, 2008), alike.

The LCA study starts with the identification of objectives. After the study system has been described the life cycle inventory (LCI) is developed as a sum of the material and energy flows in and out of the unit process. In the life cycle impact assessment phase (LCIA) of LCA the product system is examined from an environmental perspective. The inventory results are transferred into contributions to relevant impact categories, such as depletion of abiotic resources, climate change, acidification, etc (ISO 14040).

Acidification (AP) is the air emission of gasses, such as $\mathrm{SO}_{2}, \mathrm{NO}_{\mathrm{x}}, \mathrm{HCl}$ and $\mathrm{NH}_{3}$. The interaction of these gasses and other molecules of the atmosphere results in the acidification of ecosystems (Audsley et al., 1997). The acidification potential is expressed in equivalents of $\mathrm{SO}_{2}$ emissions.

Eutrophication (EP) is caused by emission of substrates and gasses (like $\mathrm{NO}_{\mathrm{x}}, \mathrm{NH}_{3}, \mathrm{PO}_{4}$ ) to the water and air that affect the ecosystem's growth pattern (De Boer, 2003). The eutrophication potential is expressed in equivalents of $\mathrm{PO}_{4}$ or $\mathrm{NO}_{3}$ emission.

Global warming (GHG) refers to the atmospheric greenhouse gasses emissions, which trap some of the reflected outgoing solar energy and retain heat somewhat like the casting of the greenhouse. Still, without this very effect, the Earth's temperature would be lower than it is and life as we know it would not be possible (IPCC, 2001). The greenhouse gas emissions are expressed in equivalents of $\mathrm{CO}_{2}$ emissions.

Tropospheric ozone precursor potential (TOPP) represents near ground ozone formation as instigator of summer smog. It is the equivalent of ozone formation calculated from ozone precursors (GEMIS, 2009).

Use of resources is nowadays treated from the perspective of non-renewable resources. However, efficient use of resources such as fuels, water and agricultural land remains an important topic in agricultural LCAs (De Boer, 2003). The resource consumption is assigned to cumulative energy use (CUE).

An important part of the employed resources is the area of land used for the production. This limited resource should not be overlooked in the studies of environmental impact concerning agriculture or forestry studies (Mattsson et al., 2000).

\subsection{CASE STUDIES}

The procedural principles of LCA were successfully applied to studies of innovative production steps of several traditional food production lines (Table 1). The case studies include the aspects of primary production (vegetable growing - fertilizer treatment, animal husbandry - nutrition and stable practices) and processing of the agricultural products (dry-cured meat) to traditional food products.

The first case study was based on fertilizer treatment field experiments conducted by the Institute for Food and Agricultural Research and Technology (IRTA). 
Table 1: Case studies considered in the framework of environmental impact assessment of traditional foods Preglednica 1: Študije, vključene v ogrodje ocenjevanja vplivov na okolje v proizvodnji tradicionalnih živil

\begin{tabular}{|c|c|c|c|c|}
\hline \multirow[b]{2}{*}{ Process } & \multirow[b]{2}{*}{ Case study } & \multirow[b]{2}{*}{ Region } & \multicolumn{2}{|c|}{ Agricultural \& production practices } \\
\hline & & & traditional & alternative \\
\hline $\begin{array}{l}\text { Fertility } \\
\text { management }\end{array}$ & $\begin{array}{l}\text { Vegetable cultivation; } \\
\text { Brassica sp. }\end{array}$ & Spain & $\begin{array}{l}\text { mineral fertilizer } \\
\text { treatment }\end{array}$ & $\begin{array}{l}\text { organic fertilizer } \\
\text { treatment }\end{array}$ \\
\hline $\begin{array}{l}\text { Feed ration } \\
\text { composition }\end{array}$ & $\begin{array}{l}\text { Vegetable oil supplementation; } \\
\text { extruded linseed. }\end{array}$ & France & $\begin{array}{l}\text { traditional } \\
\text { ration }\end{array}$ & $\begin{array}{l}\text { addition of } \\
\text { extruded linseed }\end{array}$ \\
\hline $\begin{array}{l}\text { Milking } \\
\text { frequency }\end{array}$ & $\begin{array}{l}\text { Comparison of } \\
\text { once and twice daily milking. }\end{array}$ & France & $\begin{array}{l}\text { twice daily } \\
\text { milking }\end{array}$ & $\begin{array}{l}\text { once daily } \\
\text { milking }\end{array}$ \\
\hline $\begin{array}{l}\text { Curing mix } \\
\text { manipulation }\end{array}$ & $\begin{array}{l}\text { Reduction of sodium chloride / } \\
\text { substitution with potassium lactate. }\end{array}$ & Spain & $\begin{array}{l}\text { high } \mathrm{NaCl} \text { content } \\
\text { in cured ham }\end{array}$ & $\begin{array}{l}\text { reduction of } \\
\mathrm{Na}^{+} \text {level }\end{array}$ \\
\hline
\end{tabular}

The several field experiments involved the cultivation of different Brassica varieties (Trevi, Meridien, Favola), two fertilization treatments (organic fertilizer - manure - $\mathrm{O}$; mineral fertilizer - M) were tested (Alomar et al., 2007; Doltra et al., 2008; Muñoz, 2009).

The second case study was based on nutritional research carried out by the French National Institute for Agricultural Research (INRA). The experiments were focused on the effects of dairy diet supplementation with vegetable oil on the nutritional quality of dairy fat. The ration fed to cows (Ho-Holstein, Mo-Montbèliarde) was based on different amounts of hay, maize silage, cereal mix, soybean meal and extruded linseeds with and without vitamin E (C-control/traditional, ELS-with extruded linseeds, ELSvE-with extruded linseeds and vitamin E) (Ferlay et al., 2007; Martin et al., 2008).

The third case study was based on a set of milking frequency observations carried out by INRA, likewise. The experiment consisted of three groups (TDM - cows milked twice daily/traditional, ODM - cows milked once

Table 2: Functional units and data characteristics

Preglednica 2: Funkcionalne enote in glavni viri podatkov

\begin{tabular}{|c|c|c|c|}
\hline Case study & Functional unit & Main data sources & Assigned to location \\
\hline $\begin{array}{l}\text { Vegetable cultivation; } \\
\text { Brassica sp. }\end{array}$ & $\begin{array}{l}t \text { marketable yield } \\
\text { ha of land used }\end{array}$ & $\begin{array}{l}\text { Alomar et al., } 2007 \\
\text { Doltra et al., } 2008 \\
\text { Muñoz, 2007 \& } 2009 \\
\text { MITERRA-EUROPE, } 2007 \\
\text { AEMET, } 2009 \\
\text { EUSOILS, } 2009\end{array}$ & $\begin{array}{l}\text { Lleida \& Tarragona, } \\
\text { (Cataluña, Spain) }\end{array}$ \\
\hline $\begin{array}{l}\text { Vegetable oil supplementation; } \\
\text { extruded linseed. }\end{array}$ & $\begin{array}{l}\mathrm{t} \mathrm{ECM}^{\mathrm{a}} \\
\text { ha of land used }\end{array}$ & $\begin{array}{l}\text { Ferlay et al., } 2007 \\
\text { Martin et al., } 2008 \\
\text { Martin, } 2009 \\
\text { NRC, } 2001 \\
\text { MITERRA-EUROPE, } 2007 \\
\text { GEMIS 4.5, } 2009\end{array}$ & $\begin{array}{l}\text { Marcenat } \\
\text { (Chantal, France) }\end{array}$ \\
\hline $\begin{array}{l}\text { Comparison of once and twice } \\
\text { daily milking. }\end{array}$ & $\begin{array}{l}\mathrm{t} \mathrm{ECM}^{\mathrm{a}} \\
\text { ha of land used }\end{array}$ & $\begin{array}{l}\text { Martin et al., } 2007 \\
\text { Pomiès, } 2009 \\
\text { NRC, } 2001 \\
\text { MITERRA-EUROPE, } 2007 \\
\text { GEMIS 4.5, } 2009\end{array}$ & $\begin{array}{l}\text { Monts-Dore } \\
\text { (Auvergne, France) }\end{array}$ \\
\hline $\begin{array}{l}\text { Reduction of sodium chloride / } \\
\text { substitution with potassium lactate. }\end{array}$ & $\begin{array}{l}t \text { green ham } \\
t \text { cured ham }\end{array}$ & $\begin{array}{l}\text { Fulladosa et al., } 2007 \\
\text { Gou et al., } 2007 \\
\text { Serra et al., } 2007 \\
\text { Arnau, } 2007 \\
\text { Garcia, } 2009 \\
\text { Fulladosa et al.,2009 } \\
\text { GEMIS 4.5, } 2009\end{array}$ & Spain \\
\hline
\end{tabular}

a = energy corrected milk (Sjaunja et al., 1991) 
daily, ODMc - cows milked once daily, with calves). The cows were fed ad libitum with a pre-mixed ration of grass, maize silage, hay, straw and concentrates (Martin et al., 2007; Pomiès, 2009).

The last case study was based on experiments aimed to reduce the concentration of sodium chloride in dry cured ham, performed by IRTA. Potassium lactate was used as a substitute to Sodium chloride in ham cure (S - traditional $\mathrm{NaCl}, \mathrm{SR}$ - reduction of $\mathrm{NaCl}, \mathrm{SRL}-\mathrm{NaCl}$ substitution with K-lactate) were tested in the experiment for their effect on weight loss and sensory characteristic (Arnau, 2007; Fulladosa, 2007; Gou, 2007; Serra, 2007).

\section{METHODOLOGICAL FRAMEWORK}

A well defined scope of the environmental impact assessment is essential. A highly specific LCA, for example, can be employed to discover the points in the production where the potential for environmental burdening is the highest. On the other hand, conceptual LCA can be set on evaluating the potentials of known environmental impact production hot spots (EEA, 1997).

The evident scope of these case studies was to review and assess the environmental impacts of identified production steps. Yet, the underlining goal was the overview of the suitability and development status of the LCA method, the available publicly available tools and data relevant to the agriculture and food production in the EU.

The main function of the selected processes is the production of food. Therefore, the final representation

Table 3: Framework of environmental impact assessment for studied process innovations: GHG, AP and EP categories

Preglednica 3: Konceptualni pregled postopka ocenjevanja okoljskih vplivov, okoljske kategorije: toplogredni plini, potencial za zakisanje in potencial za evtrofikacijo

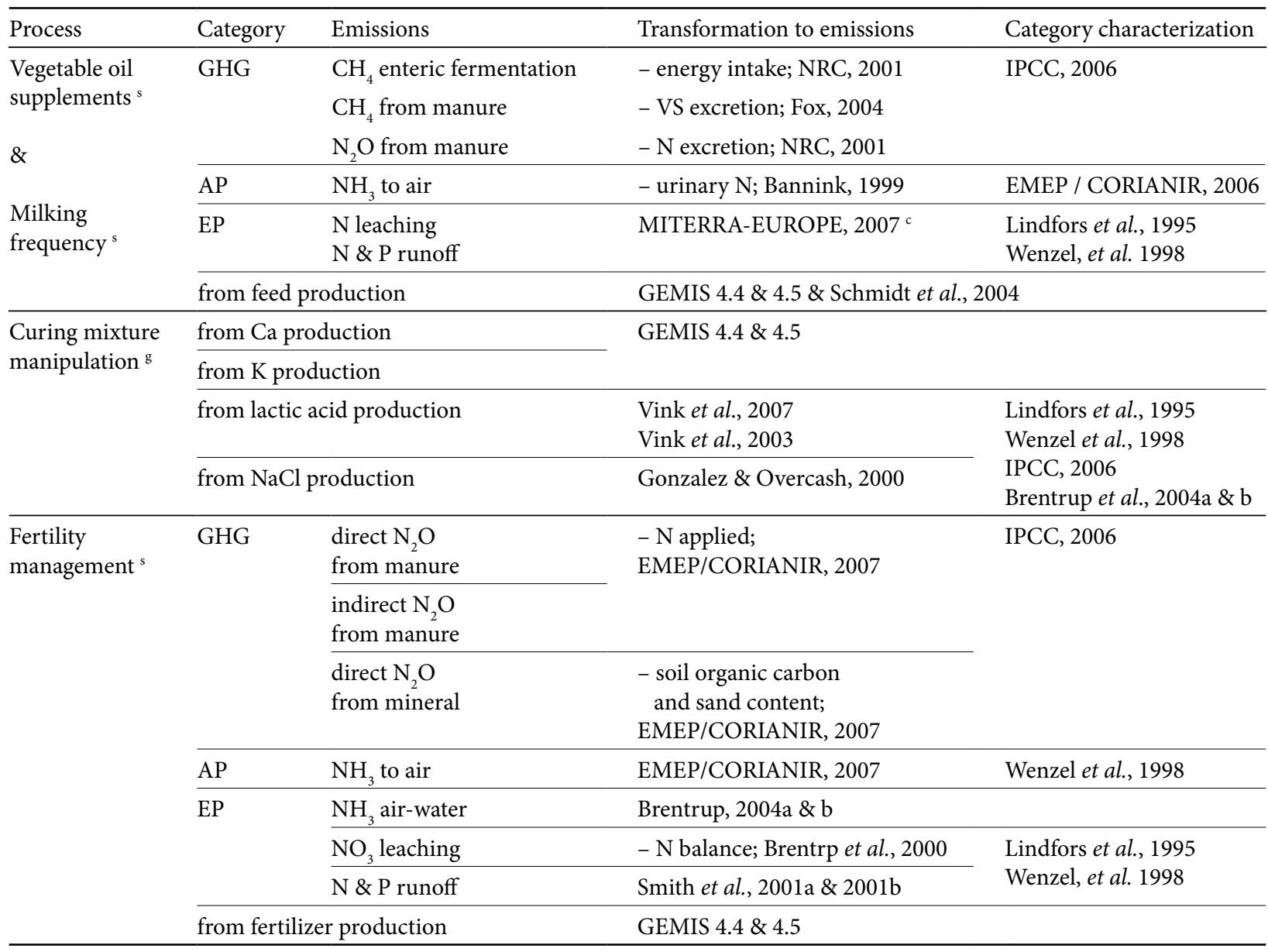

$\mathrm{c}=$ method in development; $\mathrm{s}=$ site specific; $\mathrm{g}=$ general 
the environmental impacts assessed was expressed per tone of food product and per hectare of agricultural land used for the production (Table 2).

The hot points previously identified were taken as a backbone (objectives identification \& LCI construction) for the LCA assessment boundaries (Osojnik Črnivec \& Marinšek-Logar, in press).

\subsection{INVENTORY AND CATEGORY CHARACTER- IZATION}

The experimental data obtained at INRA and IRTA (TRUEFOOD, 2009) was supported with the expert databases on e.g. fodder composition, nutrition data, weather data, soil characteristics and similar (Table 2). To obtain an emission inventory, initial parameters were coupled with models found in scientific literature. The characterization to categories was performed in accordance with available environmental impact assessment guidelines (Table 3).

Emissions to air (greenhouse \& acidification inducing substances) were assessed with the aid of EMEP/ CORINAIR Emission Inventory Guidebook (2007) and the IPCC Guidelines for National Greenhouse Gas Inventories (2006).

The preliminary results from a model-in-development, MITERRA-EUROPE, funded under the European Commission, Directorate-General Environment (service contract "Integrated measures in agriculture to reduce ammonia emissions") were used for the localization of emission eutrophication potential in the regions of the experiments.

For the vegetable cultivation case study, the amounts of nutrients in fertilizers and cauliflower marketable yield were taken as the backbone of the environmental impact assessment. Nutrient losses were estimated for $\mathrm{NO}_{3}-$ leaching (with the aid of $\mathrm{N}$ field balance, Brentrup et al., 2000, 2004a \& 2004b) and for N and P runoff (Smith et al., 2001a \& 2001b).

The $\mathrm{NO}_{3}$ leaching model required the input of climatic parameters (precipitation), which were obtained for the Cataluña region from the Spanish meteorological agency (AEMET, 2009).

The production of manure is a part of the environmental impact balance of the animal production system and it should be assigned to the animal product produced (milk, meat ...), therefore, the environmental impact of manure production in this case is null.

The production of mineral fertilizers was estimated with the aid of GEMIS 4.5 (2009).

In the case studies of vegetable oil supplementation and milking frequency, the nutritional data was taken as the basis for environmental impact assessment. In the first stage, the cows' nutritional requirements and the amounts of feed components (indigestible dry matter, crude protein \& nitrogen, phosphorus, potassium, sodium ... intake) were estimated (NRC, 2001).

The intake parameters were coupled with existent nutrition-based models (NRC, 2001; Fox, 2004) to assess the levels of excreted nutrients.

The environmental impact of feed production was modelled separately with the GEMIS 4.5 database and tool (2009). For soy meal feed component, production in the Americas and transport to EU was assumed.

Bran wheat (a component of the linseed mixture) is as by-product of the milling process. As it is in excess in the market it serves as a component in animal feed. It has been assumed (LCA Food Database, 2007) that one $\mathrm{kg}$ bran displaces one $\mathrm{kg}$ of barley.

Straw is a by-product of crop production and is the source of dietary fibre. It has been assumed that $1 \mathrm{~kg}$ of straw displaces its nutritional equivalent of roughage (approx. $0.9 \mathrm{~kg}$ hay)

The production efficiency of dairy cows accounts for milk yield and milk composition. For the standardization purposes, fat corrected milk (Gaines, 1927) - FCM (milk yield usually adjusted to 4 or 3.5\% fat) and energy corrected milk (Sjaunja et al., 1991) - ECM (milk yield adjusted to $3.14 \mathrm{MJ} / \mathrm{kg} ; 38.3 \mathrm{MJ}$ fat / kg, 24.2 protein / $\mathrm{kg}, 4.61 \%$ lactose $\& 0.2 \%$ citric acid) are commonly used. For the final expression of the environmental impact, energy corrected milk was calculated with the equation proposed by Sjaunja et al. (1991). Hence the composition of the milk in the experiment differed significantly amongst the tested groups; ECM enabled a more relevant comparison of the environmental impacts than the comparison of mere milk yields.

Additionally to the milking frequency experimental groups TDM, ODM and ODM-c, a 'calf-allocation' group, ODMc-a, was created for the calculation and evaluation purposes. In the case of the group ODMc, the full environmental impact cannot be assigned merely to milk produced, as beef meat is the outcome of the calves' production. Therefore in the group ODMc-a, the nutritional requirement of the diary cows in the ODMc group were subtracted the requirements for milk consumed by calves.

In the potassium lactate production, the production lines of potassium, calcium sulphate and lactic acid are involved (Fig. 1). Lactic acid is produced from sugars by fermentation. Agents, such as calcium sulphate are used, to neutralize the fermentation broth and fixate the product (calcium lactate is formed). For K-lactate production, the calcium ions are replaced via ion exchange with potassium (PURAC, 2009). 
GEMIS 4.5 data was used to calculate the environmental impact of calcium sulphate (gyps) and potassium production. As plaster is an input as well as an output of the production (it is recovered in the process), the environmental impact from gyps production was omitted.

The production of lactic acid was extrapolated from data reported by Vink et al. (2003) and Vink et al. (2007).

The emission inventory of González \& Overcash (2000), based on energy sub-modules was used to gain insight into the environmental impact of salt production.

Emissions to air (greenhouse \& acidification inducing substances) were assessed with the aid integrated procedures of the GEMIS 4.5 tool and additional characterization factors for greenhouse gas emissions (IPCC, 2007), acidification potential (Wenzel et al., 1998,), eutrophication (Lindfors et al., 1995, Wenzel et al., 1998, Brentrup et al., 2004) and photochemical ozone creation potential (EEA, 2000).

\section{CONCLUSIONS}

The LCA application in the agricultural sector is rapidly accelerated by the need to assess the environmental impact growing of currently controversial energy-crops (Zah et al., 2007) and a need to relevantly define the term "renewable energy".

The primary production originating from agriculture is commonly recognized as the largest contributor to the environmental impact of food production (Berlin, 2002; Foster et al., 2006, Williams et al., 2006). As the environmental impacts assessed in complex systems are prone to higher uncertainties field - standardization of the assessment procedures based on multiple screening studies is required to make the assessment outcome less venerable.

The individual array of procedures paired for each environmental impact of the observed production steps is an important result. The study - specific environmental assessment protocols, applied models and databases are suitable for latter preparation of guidelines for environmental impact assessment in specific fields of agriculture and food production.

For a relevant environmental impact several conditions have to be fulfilled. Firstly, the production data of appropriate detail have to be available. Secondly, the direct emission measurements or alternatively the methodology for conversion of the existent production data to the emissions inventory should be available, as it is not the goal of the environmental consultants to develop new assessment models.

During the environmental impact assessment of selected innovations, we encountered several appropriate and well validated models for the evaluation of nutrition-related environmental impact (e.g. NRC, 2001; Fox, 2004). The transfer of nutrients in the environment is sufficiently covered (e.g. EUROHARP, 2004), and the procedures, methods and models in the field of food production are less widespread (e.g. Foster et al., 2006; Roy et al., 2009).

As global warming is an important topic, the methodology for the assessment of GHG emissions is well established. The Intergovernmental Panel on Climate Change (IPCC, 2007) and the European Environmental Agency (EMEP/CORIANIR, 2006) both provide guidelines and workbooks for the assessment of GHG emissions applicable to the field of agriculture and food production, as well.

The assessment of the acidification and eutrophi-

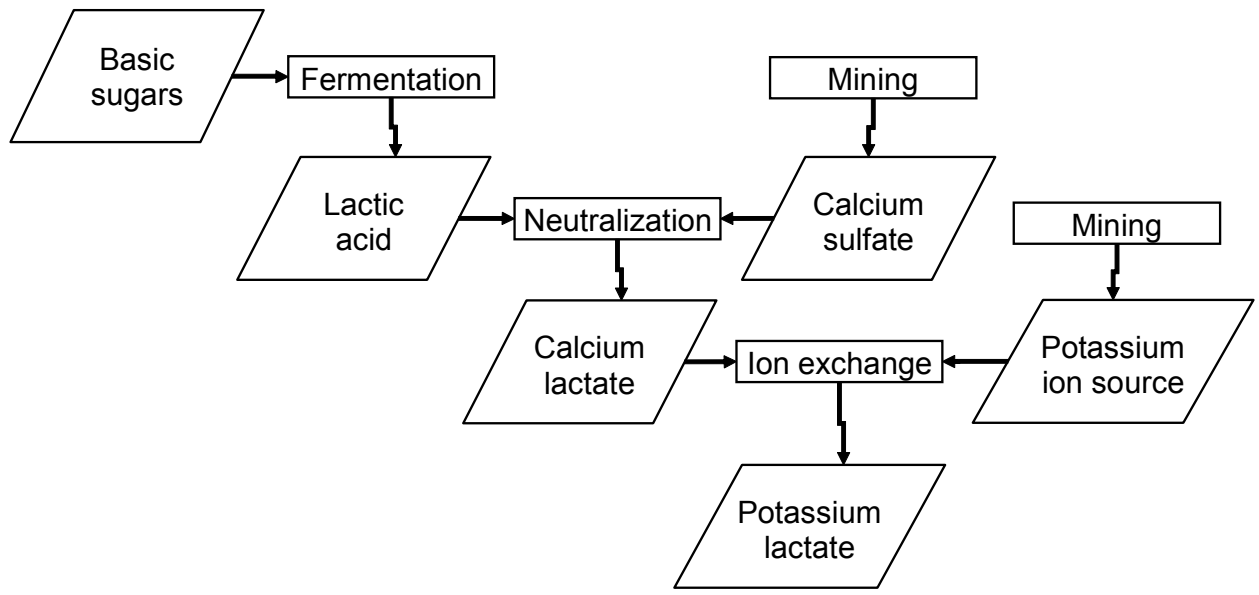

Figure 1: Production of potassium lactate

Slika 1: Proizvodnja kalijevega laktata 
cation potential is not yet a unified task. The acidification and eutrophication - related emissions in the dealt cases are specific to the production location. However, general data are available (EUSOILS, 2009), the MITERRA-EUROPE approach is inclining to the local approach (NUTS-2 resolution) and the composition of EU agricultural soils is to be mapped out (EuroGeoSurvey, 2009). The data on land use and energy consumption is not easily available, yet it can be assessed with a relative low-effort when sufficient production data is at hand. The data on photochemical ozone creation potential is commonly scarce in the public domain and should be expected to become more accessable with further development of the global warming assessment methodology.

It is necessary to widen the life cycle inventories to the national detail. Commercial databases dispose with a wide array environmental data for specific processes or products, but (at least for those connected with agriculture) their national / spatial / local relevance is questionable.

It will become necessary to assess a wider array of environmental categories for agricultural activities. Human and ecosystem toxicity, biodiversity depletion and water consumption are relevant environmental issues requiring relevant and publicly available indicators.

The example of the systematic guidelines on GHG emission assessment and/or reporting (EMEP/ CORINAIR, 2006; IPCC, 2007) should be taken forward to the construction of national environmental impact inventory guidelines. As different levels of detail are necessary for different assessment types, the procedures should be flexible and allow some different degrees of focus.

The first step towards the conceptual national guideline framework is the summarization of case-specific studies and existent guidelines. Amongst others, the guidelines on LCA tailored to production of crops (Brentrup et al., 2004a \& 2004b), soy meal (Lehuger, 2009) and farming (Thomassen et al., 2009) were taken into consideration whilst performing this environmental impact assessment.

The increasing availability of the tools (such as GEMIS, or the recently developed versatile application, openLCA) and databases (like the European based ELCD, or the NREL LCi database from the US) in the public domain, further support the development of the national and EU guideline formation (e.g. International Reference Lyfe Cycle Data System - ILCD, in development).

\section{POVZETEK}

V celokupni oceni vpliva proizvodnje živil na okolje nosijo postopki kmetijske pridelave večji delež od vseh ostalih postopkov procesiranja, razvoza in prodaje (Berlin, 2002; Foster et al., 2006, Williams et al., 2006).

Zaradi raznolikih in pogosto nejasnih postopkov ocenjevanja okoljskih vplivov nas lahko okoljsko vrednotenje kompleksnih proizvodnih sistemov privede do ocen $\mathrm{z}$ visoko negotovostjo. Vendarle pa so tudi takšne začetne študije lahko $\mathrm{v}$ pomoč pri potrebni standardizaciji področno-specifičnih postopkov presoje vpliva na okolje.

$S$ tem namenom je prvi del našega prispevka namenjen predstavitvi metodološkega ogrodja, ki smo ga uporabili za ocenjevanje okoljskega vpliva, temelječega na metodi ocenjevanja življenjskega cikla. Na podlagi predstavljenega nabora postopkov smo ocenili spremembo okoljskih vplivov pri uvajanju inovacij v proizvodnje linije na štirih primerih (raba gnojil v pridelavi cvetače, sestava obroka krav molznic, pogostnost molže in spreminjanje sestave zorilne mešanice $\mathrm{v}$ proizvodnji pršuta).

Eksperimentalne podatke smo pridobili iz inštitutov INRA in IRTA. Prejete podatke smo podkrepili s podatki iz specializiranih baz podatkov (npr. sestava krmil, vremenski podatki, sestava in značilnosti tal itd.). Proizvodne podatke smo pretvorili v emisije s pomočjo ustreznih modelov iz znanstvene literature. Iz popisa emisij smo izračunali doprinos k posameznim kategorijam okoljskih vplivov $\mathrm{v}$ skladu $\mathrm{z}$ razpoložljivimi smernicami za presojo vplivov na okolje.

Emisije v zrak (toplogredni plini in prekurzorji kislega dežja) smo ocenili s pomočjo vodnika EMEP/CORINAIR (2007) in smernicami IPCC (2006). Za geografsko umestitev ocene evtrofikacijskega potenciala smo uporabili uvodne rezultate projekta MITERRA EUROPE (2009).

V prvi fazi smo pridobljene nabore postopkov povezali individualno za oceno vpliva posameznega proizvodnega koraka na okolje. Ti študijam-specifični protokoli presoje vplivov na okolje in uporabljeni modeli ter baze podatkov so primerni tudi za kasnejšo pripravo smernic za poročanje vplivov na okolje $\mathrm{v}$ obravnavanih področjih kmetijske dejavnosti in proizvodnje živil.

\section{ACKNOWLEDGEMENTS}

The authors acknowledge the TRUEFOOD"Traditional United Europe Food", an Integrated Project financed by the European Commission under the $6^{\text {th }}$ Framework Programme for RTD (contract n. FOODCT-2006-016264). The information in this document reflects only the authors' views and the Community is not liable for any use that may be made of the information contained therein.

The contributions of the TRUEFOOD partner in- 
stitutions which have provided basic experimental and process data, especially the Institute for Food and Agricultural Research and Technology and the French National Institute for Agricultural Research are kindly acknowledged. The detailed results of the experiments are not part of this evaluation and should be obtained from the TRUEFOOD project or their appropriate partners.

\section{REFERENCES}

AEMET - La Agencia Estatal de Meteorología. 2009. http://www.aemet.es/en/portada (12. Nov. 2009)

Alomar O., Arnó J., Gabarra R., Muñoz P., Doltra J., Castelari M. 2007. Interim report on the effect of novel pest control strategies on the incidence of pests, yield and the nutritional quality of fresh lettuce, and of the effect of fertility management systems on the nutritional quality of Brassica. 2007. IRTA. A report to the TRUEFOOD project $\mathrm{N}^{\circ}$ D4.3.2-2: $13 \mathrm{p}$.

Arnau J. 2007. "The basic characteristics of the Spanish dry cured production line« IRTA (Personal communication, 23. Feb. 2007)

Audsley E., Alber S., Clift R., Cowell S., Crettaz P., Galiard G., Hasusheer J., Jolliet O., Kleijn R., Mortensen B., Pearce D., Roger E., Teulon H., Weidema B., van Zeijts H. 1997. Harmonization of Environmental Life Cycle Assessment for Agriculture. Final report to the European Commission. European Commission.

Bannink A., Valk H., Van Vuuren A.M. 1999. Intake and Excretion of Sodium, Potassium and Nitrogen and the Effects on Urine Production by Lactating Dairy Cows. Journal of Dairy Science, 82: 1008-1018

Berlin J. 2002. Environmental life cycle assessment (LCA) of Swedish semi-hard cheese. International dairy journal, 12: 939-953

Brentrup F., Küsters J., Kuhlmann H., Lammel J. 2000. Methods to estimate on-field nitrogen emissions from crop production as an input to LCA studies in the agricultural sector. International Journal of LCA, 5: 349-357

Brentrup F., Küsters J., Kuhlmann H., Lammel J. 2004a. Environmental impact assessment of agricultural production systems using the life cycle assessment methodology: I. Theoretical concept of a LCA method tailored to crop production. European Journal of Agronomy, 20, 3: 247-264

Brentrup F., Küsters J., , Lammel J., Barraclough P., Kuhlmann H. 2004b. Environmental impact assessment of agricultural production systems using the life cycle assessment (LCA) methodology II. The application to $\mathrm{N}$ fertilizer use in winter wheat production systems. European Journal of Agronomy, 20, 3: 265-279

De Boer I.J.M. 2003. Environmental impact assessment of conventional and organic milk production. Livestock Production Science, 80: 69-77

Doltra J., Ribas A., Alomar O., Gabarra R., Arnó J., Muñoz P, Castelari M., García J.A., Sárraga C. 2008. Interim report on the effect of novel pest control strategies on the incidence of pests, yield and the nutritional quality of fresh lettuce, and of the effect of fertility management systems on the nutritional quality of Brassica. IRTA. A report to the TRUEFOOD project $\mathrm{N}^{\circ}$ D4.3.2-3: $18 \mathrm{p}$.

EC-JRC (European Commission's Joint Research Centre). 2009. Life Cycle Thinking.

http://lct.jrc.ec.europa.eu/ (27. Oct. 2009)

EEA (European Environment Agency). 1997. Life Cycle Assessment, A guide to approaches, experiences and information sources. Environmetal Issue Series no. 6. http://reports.eea.europa.eu/GH-07-97-595-EN-C/en (28. Oct. 2009)

EEA. 2000. Environmental Signals 2000. European Environmental Agency, Copenhagen, Denmark

EMEP/CORINAIR.2006.EmissionInventoryGuidebook-2006. http://reports.eea.europa.eu/EMEPCORINAIR4 (20. May 2009)

EMEP/CORINAIR.2007.EmissionInventoryGuidebook-2007. http://www.eea.europa.eu/publications/ EMEPCORINAIR5/ (05. Nov. 2009)

EPA. 2009. (U.S. Environmental Protection Agency), Life Cycle Assessment (LCA). http://www.epa.gov/nrmrl/lcaccess/ (27. Oct. 2009)

EPLC. 2009. European Platform on Life Cycle Assessment. http://lca.jrc.ec.europa.eu/ (30. Oct. 2009)

EuroFIR. 2009. (European Food Information Resource Network), Traditional Foods.

http://www.eurofir.net/public.asp?id=4292 (27. Oct. 2009)

EuroGeoSurveys. 2007. Association of the Geological Surveys of Europe. http://www.eurogeosurveys.org/ (20. May 2009)

EUROHARP. 2004. http://euroharp.org/index.htm (20. May 2009)

EUSOILS - European Soil Portal Home Page. 2009. http://eusoils.jrc.ec.europa.eu/ (20. May 2009)

Ferlay A., Chilliard Y., Martin B. 2007. Interim Report on the effect of vegetable oil and/or antioxidant supplementation of dairy diets on the nutritional composition, sensory quality and oxidative stability of milk. IRTA. A report to the TRUEFOOD project $\mathrm{N}^{\circ}$ D4.1.1a-1: $12 \mathrm{p}$.

Foster C., Green K., Blenda M., Dewick P., Evans B., Flynn A., Mylan J. 2006. Environmental Impacts of Food Production and Consumption: A report to the Department for Environment, Food and Rural affairs. London. Manchester Buisness School \& DEFRA

Fox D.G., Tedeschi L.O., Tylutki T.P., Russel J.B., Van Ambrugh M.E., Chase L.E., Pell A.N., Overton T.R. 2004. The Cornell Net Carbohydrate and Protein System model for evaluating herd nutrition and nutrient excretion. Animal Feed Science and Technology, 112: 29-78

Fulladosa E., Serra X., Gou P., Arnau J. 2007. Interim report on the effect of potassium lactate and salt contents on the texture and flavour properties. IRTA. A report to the TRUEFOOD project $\mathrm{N}^{\circ}$ D4.2.3-3: $8 \mathrm{p}$.

Fulladosa E., Serra X., Gou P., Arnau J. 2009. Effects of potassium lactate and high pressure on transglutaminase restructured dry-cured hams with reduced salt content. Meat Science, 82: 213-218

Gaines W.L. 1927. The Energy Basis of Measuring Milk Yields. Journal Of Animal Science: 33-36 
Garcia N. 2009. "Details on deboning-salting-binding” IRTA (personal communication, 16. Feb. 2009)

GEMIS 4..5 -Global Emission Model for Integrated Systems. 2009. ÖKO Institut e.V.

http://www.oeko-institut.de/service/gemis/en/index.htm (28. Oct. 2009)

González C.J., Overcash M. 2000. Energy sub-modules applied in life-cycle inventory of processes. Clean Products and Processes, 2: 57-66

Gou P., Costa A., Arnau J. 2007. Interim Report on Conjoint Diffusivities of K-lactate and salt at different $\mathrm{pH}$ and temperatures. IRTA. A report to the TRUEFOOD project $\mathrm{N}^{\circ}$ D.4.2.3-1: $14 \mathrm{p}$.

IPCC. 2001. Climate change 2001. The Scientific Basis. Contribution of the working group I to the Third Assessment Report of the Intergovernmental Panel on Climate Change. Cambridge University Press

IPCC. 2006 IPCC Guidelines for National Greenhouse Gas Inventories.

http://www.ipcc-nggip.iges.or.jp/public/2006gl/index.html (12. Nov. 2009)

IPCC. 2007. Intergovernmental Panel on Climate Change. Climate Change 2007. The Physical Science Basis. Contribution of Working Group I to the Fourth Assessment Report of the IPCC. Cambridge University Press

ISO 14040. 2006. Environmental management -- Life cycle assessment -- Principles and framework

LCA food database. 2007. http://www.lcafood.dk/ (20. May 2009)

Lehuger S., Gabrielle B., Gagnaire N. 2009. Environmental impact of the substitution of imported soymeal with locallyproduced rapeseed meal in dairy cow feed. Journal of Cleaner Production, 17: 616-624

Lindfors L.G., Christiansen K., Hoffmann L., Virtanen Y., Juntilla V., Hanssen O.J., Rønning A., Ekvall T., Finnveden G. 1995. Nordic Guidelines on Life-Cycle Assessment. Nord 20. Copenhagen, Nordic Council of Ministers

Martin B., Graulet B., Pomiès D. 2007. Interim Report on the effect of once daily milking with and without calves on the nutritional composition of milk. IRTA. A report to the TRUEFOOD project $\mathrm{N}^{\circ}$ D4.1.1c-1: $9 \mathrm{p}$.

Martin B., Ferlay A., Cornu A., Chilliard Y. 2008. Final Report on the effect of vegetable oil and/or antioxidant supplementation of dairy diets on the nutritional composition, sensory quality and oxidative stability of milk. IRTA. A report to the TRUEFOOD project $\mathrm{N}^{\circ}$ D4.1.1a-3: $19 \mathrm{p}$.

Martin B. 2009. "Meal composition in the oil supplementation experiment" INRA (personal communication, 03. Mar. 2009)

Mattsson B., Cederberg C., Blix L. 2000. Agricultural land use in life cycle assessment (LCA): case studies of three vegetable oil crops. Journal of Cleaner Production, 8-4: 283-292

MITERRA-EUROPE. 2009. SC ammonia. ALTERRA research institute.

http://www.scammonia.wur.nl/UK/ (20. May 2009)

Muñoz P. 2007. "Basic characteristics of cauliflower production in Spain" IRTA (personal communication, 09. Mar. 2007)

Muñoz P. 2009. "Details on fertilizer treatment in the Brassica field experiment" IRTA (personal communication, 16. Mar. 2009)

NRC - National Research Council. 2001. Nutrient Requirements of Dairy Cattle, seventh revised ed. National Academy Press, Washington, DC, USA

Osojnik Črnivec I.G., Marinšek Logar R. 2009. Identification of Environmetal Impact Hot Spots in Traditional Food Production Lines. Acta Agriculturae Slovenica, 94, 1: in press

Pieniaka Z., Verbekea W., Vanhonackera F., Guerrerob L., Herslethc M. 2009. Association between traditional food consumption and motives for food choice in six European countries, research report. Appetite, 53, 1: 101-108

Pomiès D. 2009. "Meal composition in the milking frequency experiment" (personal communication, 3. Mar. \& 8. Apr. 2009)

PURAC: lactic acid, lactates and gluconates. 2009. http://www.purac.com/purac_com/ (20. May 2009)

Roy P., Nei D., Orikasa T., Xu Q., Okadome H., Nakamura N., Shiina T. 2009. A review of life cycle assessment (LCA) on some food products. Journal of Food Engineering, 90: 1-10

Schmidt A.C., Jensen A.A., Clausen A.U., Kampstrup O., Postlethwaite D. 2004. A Coparative Life Cycle Assessment of Building Insulation Products made of Stone Wool, Paper Wool and Flax. International Journal of LCA, 9,1: 53-66

Serra X., Fulladosa E., Gou P., Arnau J. 2007. Interim report on the effect of novel deboning-salting-binding methodologies. IRTA. A report to the TRUEFOOD project $\mathrm{N}^{\circ} \mathrm{D} 4.2 .3$ 4: $14 \mathrm{p}$.

Sibbel A. 2007. The sustainability of functional foods. Social Science \& Medicine, 64, 3: 554-561

Sjaunja L.O., Baevre L., Junkkarinen L., Pedersen J., Setala J. 1991. A Nordic Proposal for an Energy Corrected Milk (ECM) Formula. EAAP Publication No. 50: 156-157

Smith K.A., Jackson D.R., Pepper T.J. 2001a. Nutrient losses by surface run-off following the application of organic manures to arable land. 1. Nitrogen. Environmental Pollution, 112, 1: 41-51

Smith K.A., Jackson D.R., Withers P.J.A. 2001b. Nutrient losses by surface run-off following the application of organic manures to arable land. 2. Phosphorus. Environmental Pollution, 112, 1: 53-60

Tomassen M.A., De Boer I.J.M. 2005. Evaluation of indicators to assess the environmental impact of dairy production systems. Agriculture, Ecosystems and Environment, 111: 185-199

Tomassen M.A., Dolman M.A., van Calker K.J., de Boer I.J.M. 2009. Relating life cycle assessment indicators to gross value added for Dutch dairy farms. Ecological Economics 68, 8-9: 2278-2284

TRUEFOOD. 2009. (Traditional United Europe Food), Project Results, http://www.truefood.eu/page.asp?ID=23 (12. Nov. 2009)

Vink E.T.H., Rábago K.R., Glassner D.A., Gruber P.R. 2003. Applications of life cycle assessment to NatureWorks ${ }^{\mathrm{TM}}$ polylactide (PLA) production. Polymer Degradation and Stability, 80: 403-419

Vink E.T.H., Glassner D.A., Kolstad J.J., Wooley R.J., O’Connor R.P. 2007. The eco-profiles for current and near-future $\mathrm{Na}$ - 
tureWorks ${ }^{\circ}$ polylactide (PLA) production. Industrial Biotechnology: 58-81

Wenzel H., Hauschild M., Alting L. 1998. Environmental assessment of products. Volume2: Scientific background. Springer: $584 \mathrm{p}$.

Williams A.G., Audsley E., Sandars D.L. 2006. Determining the environmental burdens and resource use in the production of agricultural and horticultural commodities. Main report, DEFRA research project IS0205. Bedford. Cranfield University \& DEFRA

Zah R., Böni H., Gauch M., Hischier R., Lehmann M., Wäger P. 2007. Ökobilanz von Energieprodukten: Ökologische Bewertung von Biotreibstoffen. Bern, EMPA: 206 p. 